\title{
High-performance work system practices in Vietnam: a study of managers' perceptions
}

Article

Accepted Version

Do, H., Budhwar, P. and Patel, C. (2019) High-performance work system practices in Vietnam: a study of managers' perceptions. Journal of Organizational Effectiveness: People and Performance, 6 (3). pp. 145-160. ISSN 2051-6614 doi: https://doi.org/10.1108/JOEPP-07-2018-0048 Available at https://centaur.reading.ac.uk/89983/

It is advisable to refer to the publisher's version if you intend to cite from the work. See Guidance on citing.

To link to this article DOI: http://dx.doi.org/10.1108/JOEPP-07-2018-0048

Publisher: Emerald

All outputs in CentAUR are protected by Intellectual Property Rights law, including copyright law. Copyright and IPR is retained by the creators or other copyright holders. Terms and conditions for use of this material are defined in the End User Agreement.

www.reading.ac.uk/centaur 
Central Archive at the University of Reading

Reading's research outputs online 


\title{
High-Performance Work Systems Practices in Vietnam: A Study of Managers' Perceptions
}

\author{
1. Hoa Do, $\mathrm{PhD}$
}

Lecturer in HRM/Management

Faculty of Business Administration

Ton Duc Thang University

19 Nguyen Huu Tho Street, Tan Phong ward, District 7,

Ho Chi Minh city, Vietnam

Tel: +84-283-7755067

Fax: +84-28 37755055

E-mail: dovanhoa@tdtu.edu.vn

Hoa Do is a lecturer in HRM/Management at the Faculty of Business Administration, Ton Duc Thang University, Vietnam. He received his PhD from Aston Business School, UK. His research revolves around the investigation of HPWS and innovation, which has been published in the Human Resource Management, International Small Business Journal, Journal of International Management, and presented in leading international conferences such as the Academy of Management, British Academy of Management, European Association of Work and Organizational Psychology. He is an associate fellow of the Higher Education Academy.

2. Pawan Budhwar, PhD - Corresponding Author

Professor of International HRM

Aston Business School

Birmingham, B4 7ET, UK

Tel: +44-121-2043049

E-mail: p.s.budhwar@aston.ac.uk

Pawan Budhwar is a professor of international HRM at Aston Business School, UK. He has written over 100 articles in leading journals (such as Human Resource Management, Organizational Behavior and Human Decision Processes, the Journal of International Business Studies, the Journal of Organizational Behavior, Human Relations, and Organization Studies) on people management-related topics with a specific focus on India and also written and/or co-edited 20 books on HRM-related topics. He is a Joint Director of the Aston India Centre for Applied Research, and Co-Editor-in-Chief of British Journal of Management.

\section{Charmi Patel, PhD}

Associate Professor in International HRM

Henley Business School

University of Reading 


\section{HumSS 272B}

Greenlands, Henley-on-Thames RG9 3AU, UK

E-mail: charmi.patel@henley.ac.uk

Charmi Patel is an associate professor in International HRM at Henley Business School, University of Reading. Her research following through from her $\mathrm{PhD}$ looks at how individuals relate to their work, occupations and organisations. Her research is interdisciplinary in nature, importing sensibilities from sociology, psychology as well as management to better understand the employee-organisation relationship. She has published articles in leading scholarly journals including the Human Resource Management (US, FT-45), Journal of World Business, Human Resource Management Review, International Journal of Human Resource Management, and European Journal of International Management. 


\title{
High-Performance Work Systems Practices in Vietnam: A Study of Managers' Perceptions
}

\begin{abstract}
Purpose - The primary purpose of this study is to explore the effects of high-performance work systems (HPWS) on the performance of Vietnamese firms. It teases out the antecedents and effects of managers' beliefs about why HPWS exist and are adopted within their firms, and also what effects HPWS practices have on their firm's performance.

Design/Methodology - We adopt a longitudinal design to provide insights into why and how HPWS are shaped and diffused, and also how they convert the inputs into outputs such as HR outcomes, firm innovation and performance, based on a sample of 17 in-depth interviewees who were CEOs, HR managers, general managers in 17 Vietnamese service firms.

Findings - Results demonstrate that HPWS can impact both employee outcomes (e.g., employee attitudes, behaviors, productivity), and firm performance (e.g., firm innovation, firm growth, profit growth).

Research limitations/implications - Limitations of the study include purely qualitative data, single source of data collection, and small sample size.

Originality - This is among the first study to extend some aspects of institutional theory to understand the context of how and why HPWS are shaped and executed to respond to environmental pressures. It underscores the importance of HPWS as a response to organizational change that can help deal with external pressures, thereby serving as a leading step to yield meaningful outcomes with respect to the advancement of this research stream.
\end{abstract}

\section{Keywords}

HPWS, innovation, institutional theory, qualitative content analysis, Vietnam 


\section{INTRODUCTION}

HPWS are now an established research theme in the strategic HRM field as it enables firms to achieve higher performance (Shin and Conrad, 2017). This argument is theoretically and empirically documented in recent studies (e.g., Heffernan and Dundon, 2016). In particular, HPWS have been demonstrated to be important for fostering firm ambidexterity (e.g., Patel, Messersmith and Lepak, 2013), increasing job involvement (Huang, Ahlstrom et al., 2016), contributing to firm innovation (Fu, Flood et al., 2015), improving service performance (Flinchbaugh, Li, Luth and Chadwick, 2016), among others. Despite the growing popularity of research on HPWS, scholars criticise it for the lack of theoretical advancement; methodological pitfalls; imbalance between quantitative and qualitative research; and an imbalance between Western and non-western research (e.g., Michaelis, Wagner and Schweizer, 2015).

In light of the above, this study draws on a two-wave series of 17 semi-structured interviews with managers that was obtained from 17 service firms in Vietnam. Our starting point is that we seek to understand the nature of how and why HPWS exist and are diffused in the context of Vietnam. We go beyond this by drawing upon the resource-based view (RBV) (Barney, 1991) and extending some aspects of institutional theory (Hughes, Powell, Chung, and Mellahi, 2017; Lewis, Cardy and Huang, in press) to tease out the antecedents and effects of managers' beliefs about why HPWS exist and are adopted within their firms, and also what effects HPWS practices have on their performance. Accordingly, the study seeks to address three research questions. First, what do Vietnamese managers experience and perceive about HPWS in general and HPWS practices within their organizations in particular? Second, to what extent are HPWS practices implemented effectively in their organisations, and what kinds of performance metrics provide evidence about their effectiveness? Third, is there a relationship between HPWS and innovation, if yes, to what extent do HPWS influence organizational innovation?

The study contributes to the existing literature in four different ways. First, it is one of the few studies to provide insights into the implementation of HPWS that was interpreted via managers' perceptions and voices, thereby adding new data to the literature. Managers are in an optimal position in understanding about the purpose and intent of the HRM practices that their firms employ, especially in today's highly dynamic environments where organizations face lots of external pressures. In this relation, it is necessary to focus on the macro context of 
HRM or macro-level theorizing of HRM to understand how and why HRM practices can react to environmental pressures (e.g., Lewis et al., in press). We therefore argue that managers' perceptions of their HRM practices are highly salient in this regard.

Second, this study employs a longitudinal design to explore the HPWS effects on firm performance, thereby helping bridge a method gap in HPWS research given there is a scarcity of rich in-depth longitudinal data to interpret HPWS utilisation. Third, this study also confirms the construct of innovation as a critical outcome of HPWS leading to overall performance. This is particularly significant considering regular calls made by scholars to examine new mediating variables to unveil the 'black box' HPWS and performance relationship (e.g., Werner, 2011). Finally, this study is conducted in Vietnam, which is now regarded as an important emerging market with its profound innovation in people management at large and HRM in particular (Do, Budhwar and Patel, 2018). The study therefore contributes to a nuanced understanding of HPWS practices in an interesting and understudied context - Vietnam.

This study adopts RBV of the firm to examine why and how HPWS are diffused in Vietnamese firms. As per RBV, HR is considered as a source of competitive advantage adding value to firms, especially highlighting the importance of the HR function to their strategic goals (Barney, 1991). Following this logic, it is argued that HPWS are 'a reasonable investment in the people who constitute the organization-specific human capital driving firm performance' (Shin and Konrad, 2017, p. 5). This is because well-adopted HPWS can generate mechanisms that make rivals hard to imitate, thereby creating sustained competitive advantages to those implementing HPWS (Shin and Konrad, 2017). In this relation, we argue that RBV further helps explain how HPWS yield sustained competitive advantages to firms. To illustrate this further using institutional theory, we argue that "many factors that shape HRM practices are external to the organization' (Lewis et al., in press, p. 1). In this relation, institutional theory is the salient means by which HRM can impact such external pressures. As such, we argue that both RBV and institutional theory need to be coherently combined in order to offer insights into the nature of how and why HPWS are adopted and diffused in Vietnam.

\section{LITERATURE REVIEW}


It is widely acknowledged that HPWS are a key ingredient in leading organizations to higher performance, effectiveness and long-term survival in today's turbulent business environment (Do et al., 2015). That is those organizations that optimally invest in HPWS practices often outperform those that do not. It has therefore drawn much attention from SHRM scholars who have extensively explored the underlying mechanisms through which organizations convert the inputs of HPWS into outputs. HPWS are consistently conceptualised as a set of HR practices 'designed to enhance employee's skills, commitment and productivity in such a way that employees become a source of competitive advantage' (Datta, Guthrie and Wright, 2005, p. 135). This conceptualization highlights the influence of HPWS on both HR outcomes (e.g., employee skills and abilities, attitudes and behaviours; and operational outcomes such as productivity) (Jiang et al., 2012). Following this logic, scholars hold that assuming that employees are potentially strategic resources for an organisation, HPWS serve to transform organisational members into organisational strategic resources, and thereby support organizational competitive advantage by enhancing employee contributions to organisational performance (Pak and Kim, 2018). In short, HPWS play an important role in generating, developing, and deploying employee skills and abilities as well as their motivation, attitudes and behaviours in order to maximise their performance to compete against competitors.

While it is widely accepted that HPWS are critically linked to a bundle of both individual and organisational outcomes (e.g., Jiang et al., 2012), some scepticism still lingers about how HPWS truly impact performance (e.g., Pak and Kim, 2018). By this logic, HPWS research has become very timely and emerged as an important research stream. However, some of the research gaps and issues including the insights into the effects of HPWS on employee performance remain modest (Aryee et al., 2012), and the mechanisms underlying this link have not been fully highlighted (Sun et al., 2007). This concern has also been identified by other researchers with issues such as lack of clarity; mixed results and underdeveloped theoretical underpinning and without explaining causality between HPWS and performance (Shin and Konrad, 2017). Some researchers are concerned with particular facets of this finding. For example, Messersmith et al. (2011, p. 1105) conclude that there is fairly robust evidence that HPWS 'work' but are less clear as to exactly how this link unfolds. Further research is therefore needed to address these gaps. In response, this study attempts to fill such gaps. It is noteworthy that these gaps have all stemmed from quantitative studies, and relatively little is known from the qualitative research side. One can argue that findings of 
qualitative research may provide useful insights and help open up the 'black box' of HPWSperformance link.

As highlighted above, while a wealth of studies exploring the HPWS and performance relationship have been undertaken in developed countries, such research is lacking in the newly emerging markets like Vietnam. This study aims to fill this gap.

\section{The Vietnamese context for HPWS}

The need to generalise western assumptions about HPWS is highly important when taking into account a country like Vietnam, which is now emerging as a country of change, innovation and global integrity. This is well aligned with the view that Vietnam is a country undergoing significant changes, and thus generational subculture represents an important means of elucidating this change process (Cox, Hannif and Rowley, 2014). The Vietnamese government is highly determined to enable its enterprises to survive, strive and succeed in highly competitive market environments, and lead Vietnam to become an industrialised country in the future. Vietnamese businesses are currently stimulated to shape and execute innovative HR practices to attract and retain the talented to increase their competitive position in the industry (Qiao et al., 2009). In particular, enterprises seek to strategically align their HRM practices with environmental expectations with a view to achieving their legitimacy (see Lewis et al., in press).

Further, observations of changes point out that the young Vietnamese lead very different lives from those of their parents and grandparents (Kolh, 2007), i.e., they are more open and willing to adapt to and learn new things from Western cultures. By this logic, Vietnamese firms tend to make use of this trend in order to change, innovate and internationalize themselves in the era of globalization. Consequently, there have been significant changes in the Vietnamese business landscape and labour markets leading to different challenges for organizations, thereby making the management of people a key issue (Rowley et al., 2007). This situation may have much higher acceptance levels to newly imported management initiatives and practices which used to be considered inappropriate. Hence, Vietnamese firms now give a priority to invest in people management to uphold and enhance employee productivity and global competitiveness (Montague, 2013) as well as wish to pursue models of firm innovation in order to ensure their higher performance, success and long-run survival. 
Given its complex situation in the process of transition, innovation and global integrity, Vietnam is said to confront its institutional complexity due to its political, legal and cultural issues. This institutional complexity therefore greatly influences the context of HRM (Lewis et al., in press). As such, we argue that organizational context is viewed as the highly important means by which HRM may impact external pressures in which organizations are operating. This is aligned with one aspect of institutional theory that institutional complexity may become both a challenge and an opportunity confronting HRM practices within organizations depending on how they respond to external pressures (Lewis et al., in press). In this relation, the extent to which HRM practices are shaped and adopted within organizations will greatly depend on how environmental or market forces drive organizational change (Lewis et al., in press). Thus, institutional complexity may become both a challenge and an opportunity confronting HRM practices across Vietnamese firms depending on how they respond to external pressures.

\section{METHODS}

\section{Procedure}

The study deviates from prior research by conducting two waves of data collection in order to provide an insightful picture of how and why HPWS influence firm performance. Using the list of firms in two large cities (Ha Noi and Thanh Hoa) provided by VCCI, we contacted the manager or the HR manager of 30 firms for their participation in the research. Seventeen firms agreed to participate in the research and also provided us the time and place for the interviews to take place. During Time 1, we interviewed the manager or HR manager of each research service firm in 2013. Details of the industry sectors covered in this study are available in Table 1. We developed an interview schedule and shared it with the participants for confirmation and reminder. The interviews ranged from 30 to 90 minutes in duration, depending on the interviewees' interest and knowledge. During Time 2 (in 2017), we again approached the firms and managers who had participated during Time 1 to validate the Time 1 data. We were fortunate to get access to the same research participants from Time 1 investigation and they agreed to participate again in our study. We followed the same procedures of data collection as Time 1 . However, it is noteworthy that the purpose of this phase was to validate the accuracy of the Time 1 data, thereby mainly focusing on the main aspects of the interview questions such as conceptualization of HPWS, performance 
outcomes, the HPWS and innovation relationship and changes in HPWS practices between Time and Time 2.

Insert Table 1 about here

\section{Conducting the interviews}

As the research focused on studying managers' perceptions of HPWS adoption, a standard definition of HPWS (Datta et al., 2005) was included in a cover letter sent to the respondents. Prior to starting with each interview, the nature and purpose of the research was summarized to each respondent. It was highlighted that it was the respondents' opinions that were being sought, that there was no quest for 'right' or 'wrong' answers to the questions, and that no prior 'technical' knowledge of any kind was either assumed or required (O'Dwyer, 2004). Throughout the interviews, the respondents were probed and provided direction and/or clarification when things were not clear to them to ensure clarity of responses. Also, a brief summary was given to the interviewees after each theme of HPWS was discussed, to ensure that the researcher understood what they had said in the interview. It should be noted that due to the research firms' norms, the interviews were not allowed to be audio recorded. To handle this restriction, a form was designed that was used to capture and log responses from the interviewees. After each interview, an outline of the interview was written up at once and then sent to the respondent for verification and further comment. This was further validated during Time 2 of the study.

\section{Data analysis}

Considering the purpose of the study and the nature of three research questions, the responses of interviewees were analysed employing the content analysis technique. It is one of the most popular methods used for analysing qualitative data and interpreting its meaning (e.g., Hsieh and Shannon, 2005). The interview information was noted, summarized and subsequently translated into English for the purposes of analysis.

Three stages of data analysis were deployed: data reduction, data display and data interpretation (O'Dwyer, 2004). The main objective of the data reduction phase is to detect key themes and patterns in the data gathered. As the interviews were conducted in 
Vietnamese, the scripts were translated into English for analysis. Adopting the interview protocol as a broad framework, the interviewed scripts were read, revisited and reread again and again by the researchers. Consequently, the initial themes emerging within the framework were identified and then they were noted in the word file. This process of coding allowed the reduction of the transcript evidence, and also provided a means of interacting with and thinking about the evidence, thereby stimulating processes of reflection (O'Dwyer, 2004).

In the data display phase, we formed detailed matrices comprising key themes and patterns detected in each translated script so as to visually display the themes emerging when the initial codes were developed (O'Dwyer, 2004). The data interpretation involved interpreting the reduced data sets stemming from the data reduction and data display stages. The detailed notes, interviews' scripts and journal were revisited and analysed in conjunction with a study of the final summary matrices (O'Dwyer, 2004). This led to the formulation of an initial 'thick' description of the interview findings employing the interview protocol as a broad framework. Segments of translated scripts which were organized according to the core code/theme were then selected from these script segments in order to add richness to the findings developed (O'Dwyer, 2004). This stage ended with the adoption of the analytical lens to write up using an iterative process. For the Time 2 of data collection and analysis, we followed the same procedures as for the Time 1.

\section{RESULTS}

The results of the interviews (two times of data combined) indicate that the respondents demonstrated their understanding of and experiences of HPWS practices in the Vietnamese context. The perceptions of HPWS and HR-related issues are, therefore, grouped into two key themes (HPWS within firms and HPWS and innovation relationship). For reporting purposes, we code the interviewees as follows: $\mathrm{HRM}=$ human resource manager; $\mathrm{FM}=$ firm manager; $\mathrm{CEO}=$ chief executive officer; $\mathrm{GM}=$ general manager; banking $=\mathrm{B}$; pharmaceuticals $=\mathrm{P}$; telecommunications $=\mathrm{T}$; insurance $=\mathrm{I}$; time $=\mathrm{T}$.

\section{HPWS Adoption within Firms}

This theme is categorized into different sub-themes: conceptualization of HPWS, HPWS practices, influence of HPWS, and performance indicators. By doing so, we aim to address research question 1 . 


\section{Conceptualization of HPWS}

After being provided a standard definition of HPWS, the managers were asked to give their own definitions of HPWS based on their own understanding and work experiences. The interview evidence indicates that the majority of definitions provided by the managers share some degree of similarities with the existing ones in the HPWS literature (Patel et al., 2013). This is empirically evidenced and validated during Time 2 of data collection. A typical explanation given was (see more in Appendix):

HPWS are a system of HR practices targeting towards employee skills, job performance, labour productivity, commitment for their assigned tasks and enabling them to work and experience in a competitive market environment, which in turns enhances firm outcomes (BHRM, T1, 2).

The above quote indicates that HRM can be used as a means to improve employees' skills, knowledge and motivation, thereby fulfilling their duties and performance. Once employees are skilled, knowledgeable, and motivated, they are likely to respond to their firm's investment by expanding more effort to perform their duties. To this end, they can significantly contribute to firm outcomes, and thus help the firm to achieve its set goals. This argument is further supported by the following representative comment:

HPWS are a bundle of HRM policies and practices with the objective of using appropriate labour to improve work productivity and effectiveness in order for the firm to achieve its sustainable development and goals (BHRM, T1).

However, each of the definitions demonstrates its own characteristics due to the respondents' knowledge, understanding and real experience. One typical example is that the interviewee emphasized the efficacy of HPWS on both employees and managers (see more in Appendix):

HPWS are a system designed to enhance work efficiency for the staff and management at all levels of an organization, thereby achieving the goals set out at an early stage with the lowest risk (BFM, T1).

Another intriguing example includes:

HPWS refer to the building of an employee team whose specialized knowledge, skills and expertise are suitable for the business lines that an organization is operating. In addition, employees need to be equipped with other qualities such as dynamic and 
creative ability, and other soft skills such as foreign languages, information technology and communication (IHRM, T1).

Also, of interest is that although Vietnamese managers are now more open and willing to acquire new and Western styles of leadership and management, they are still partially influenced by the Vietnamese management styles and political regime. That is why they often speak of such things as mechanisms and paperwork-related issues. The following quote proves this argument:

HPWS mean working more efficiently and yielding superior performance. It is a system of processes, regulations and policies that aim to help improve the working capacity of workers and create sustainable values for an organization (BHRM, T1).

\section{HPWS practices within firms}

Extant literature demonstrates that HPWS practices have been adopted differently by different researchers, research contexts and purposes (e.g., Liao et al., 2009). Accordingly, there has been a lack of consensus on the optimal configuration of such practices that should be utilised (Aryee et al., 2012). Liao et al. (2009), for example, include nine dimensions such as training, information sharing, pay and job design. Nonetheless, when Aryee et al. (2012) adopted this scale, they excluded the information sharing dimension because of its overlap with the domain of empowerment climate. As critical as HPWS is to the understudied Vietnamese context, this interview question was probed in-depth to uncover the use and methods of HPWS within firms. The evidence shows that there are a number of HR practices, such as recruitment and selection, training and development, financial incentives that are frequently implemented in all the firms under study. However, some HR practices vary due to firms' strategies, goals and cultural factors. Based on the results of coding, the HPWS practices encompass a variety of sub-themes. The sub-themes of HPWS practices are summarised in Table 2.

Insert Table 2 about here 
Our data analysis demonstrates that most of the managers perceived the positive impact of HPWS on organizational performance except in one case. Nevertheless, it should be noted that managers' perceptions about the effectiveness of HR practices on performance could vary. In this regard, some have highlighted their firms' labour productivity, finance, market, and service performance while others have underscored HR outcomes such as employee attitudes and behaviours, and competences. The following comment was fairly typical (see more in Appendix):

Our firm has adopted these practices for over the past 8 years, and I find that they positively influence labour productivity and financial performance. This is because when we have the best people alongside with the supportive work environment, employees can develop to their full potential, thereby resulting in better labour productivity, which then contributes to our firm's outcomes (PFM, T2).

The above interviewees perceived the effectiveness of HR implementation on employee attitudes, commitment and productivity, and subsequently firm performance. The impact of HPWS on performance seems to go beyond the usual outcomes by engaging employees in the change or innovation process, making them participate in the firm's decision-making process and being responsible for what they do. Some of the managers provided the following evidence in this regard (see more in Appendix):

In order to execute HRM practices, we, the management, always attempt to engage our subordinates in the common goals setting of the firm. We create more opportunities for them to join the change process, make them feel to be a part of firm's purpose, and consequently make them willing to be in charge of their job duties, leading the firm to obtain better results (IFM, T1).

Interestingly, whilst the majority of interviewees referred to employee and firm general performance in terms of employee attitudes, behaviours, commitment and skills, and firm financial performance, some of the managers spoke of another type of performance 'corporate reputation' that is unusually detected in the extant literature:

We can experience better corporate reputation on the labour market and the business market (IGM, T1).

\section{Indicators of Performance}


Though all the respondents were from the service sector, their perceptions of performance indicators varied considerably. According to the managers 'experience, the outcome indicators that were most frequently used in their firms are summarized in Table 3.

Insert Table 3 about here

Interestingly, the interviewees also drew attention to a variety of other indicators. Some of the managers focused on employee performance, such as employee commitment and attitudes, employee satisfaction, employee loyalty and job satisfaction. Others, however, spoke of other kinds of performance, such as market expansion, capital capability, new services, new customers and business activities. Also, of interest is that one even mentioned firm brand, and another viewed firm image as a kind of organisational performance.

In short, the above findings (both of Time 1 and validated and proven in Time 2) suggest that the studied firms have experienced a number of both individual and firm level performance outcomes such as employee attitudes and behaviours, labour productivity, firm growth, market performance and higher service quality.

\section{HPWS and innovation relationship}

Our findings lie in the influence of HPWS on firm innovation. The results are well aligned with recent studies that highlight the important outcome - innovation (e.g., Fu et al., 2015; Hughes et al., 2018). Evidently, one of the interviewees commented, 'HR practices impact an organization's innovation because right $H R$ practices, which are related to training, employee opportunities to improve their skills and knowledge, and consequently have new thinking. Engaging all members in the common goals, letting them understand and take part in the common working process can generate ideas for innovation' (BFM, T1). This sentiment represented the findings of the whole research. Both Time 1 and Time 2 evidence demonstrates interviewees' consistency in their experiences that there is a close relationship between HPWS and firm innovation. This was evidenced in the following quote (see more in Appendix).

I would say that the optimal use of HR practices can motivate employees to innovate in their work, thereby productively accomplishing their job duties and subsequently 
contributing to firm performance. Therefore, employee creativity is the key to firm innovation (THRM, T2).

However, the interview evidence also revealed a very striking point when managers emphasized the role of people as a bridge between HPWS and organizational innovation. The reason behind this is that people are the key to the success of a firm (e.g., Damanpour et al., 2018). If the firm possesses the best people with higher levels of skills, knowledge and competences, they will reach their full potential. For example, they will accomplish their job duties and provide higher quality of service for customers, thereby leading to superior performance. As such, we argue that this workforce can help achieve competitive advantage, which in turn becomes a key contributor to firm performance. The following typical quote demonstrates this assertion (for details see Appendix).

As I said earlier, people are the key to all activities of the firm. If we wish to innovate, we need to have people with new and innovative thinking. Therefore, I reckon that the use of HR practices has an effect on firm innovation because if these practices are effectively implemented, they will facilitate employee attitudes, behaviour and creativity, and subsequently lead to their job productivity (BHRM, T1).

\section{Remarks of changes in HPWS practices between Time 1 and Time 2}

The data analysis at Time 2 suggests that there is consistency in the managers' experiences and beliefs about why and how HPWS are adopted and executed in the studied firms between Time 1 and Time 2. However, there are some minor changes in terms of how HPWS practices are implemented and the effects they have on firm performance. With respect to the former, the managers claim that the HPWS practices have been consistently and uniformly adopted and executed over time. Yet, to increase the efficacy of such practices, their organizations usually review and evaluate them on an annual basis. If they identify any single HR practice that is inappropriate or ineffective, the managers immediately ask their HR departments and other relevant departments and/or units to sit together to figure out the best solution to improve their HR policies and practices. This was evidenced in the following quote:

Being aware of the importance of our employees' knowledge, skills and motivation to our productivity, our company now pays more attention to organizing specific training programs that aim to equip them with both hard and soft skills so that they can be competent enough to accomplish their job duties. We also continue to complete our 
effective performance system that evaluates our employees based on their competence and performance outcomes. And other HR practices such as pay, compensation and rewards are regularly improved and updated year after year in accordance with our firm performance as well as the labour market (BFM, T2)

As regards the latter, the managers stated that HPWS are the key ingredient that helps their organizations increase their performance. HPWS not only influence their firm performance (e.g., market performance, profits, firm growth), but also positively affect their employee attitudes and behaviours such as their higher responsibility, self-consciousness, job engagement, commitment and creative behaviours. The following quote supports this argument.

I would say that HPWS have a positive impact on our business performance. For our firm performance, HPWS help us to gain higher profits and expand our markets year after year. For our employees, we have witnessed their changes in their responsibility, job engagement, commitment and presentism (TFM, T2).

Also, of interest is that Vietnam, as a newly emerging market, is undergoing lots of changes in order to go global and respond to external pressures. Along with this trend, Vietnamese firms are also facing their institutional changes, thereby being institutionally complex environments. To this end, firms must shape HR structures that can respond to external environments with a view to lessening the challenge and seizing the opportunity of such environments. Accordingly, HR departments within firms play a key role in allowing them to do so. This argument is evidenced in the quote below.

In a rapidly changing world, we need to constantly change and innovate our management practices in order to adapt to and respond to environmental uncertainty. In doing so, our firm assigned HR department to devise and renew HR policies and practices that are suited to and respond to external pressures (THRM, T2).

\section{DISCUSSION}

Early studies demonstrating the HPWS and performance relationships have mainly relied on cross-sectional quantitative data where scholars test such relationships (Shin and Konrad, 2017). Though pioneering scholars have recently started using longitudinal data to examine the linkage between HPWS and performance (e.g., Shin and Konrad, 2017) to take this 
research field forward. We contribute to this aspect by examining the effects of HPWS on firm performance using longitudinal qualitative data with two points in time. The two-time data collection results help address the three raised research questions in terms of (1) the context of how and why HPWS exist and are adopted within Vietnamese service firms, (2) what effects HPWS practices have on their firm performance, and (3) the effects of HPWS on firm innovation.

Our results highlight the antecedents and effects of managers' beliefs about why HPWS exist and are adopted within their firms. In particular, most of the managers stated that HPWS are a key ingredient that helps organizations to foster their human capital (e.g., competent and properly motivated employees), which in turn enable the organization to achieve their goals (also see Gerrard and Lockett, 2018). This is especially in today's market environments by which organizations must respond to external pressures (e.g., Xia and Liu, 2018). To do so, organizations do steadily become aware of new choices, practical solutions and management initiatives to react to such environmental pressures. Of the reactions, HPWS are the salient means that may allow organizations to respond to such external pressures (Lewis et al., in press). The results therefore help shape the context of why and how HPWS exists and is diffused in Vietnam, thereby addressing research question 1.

Drawing on the interview protocol, the findings demonstrate that HPWS positively influence both employees and their organizations. The majority of managers perceived that HPWS impacted employee performance, such as employee attitudes, behaviours, motivation and productivity. With respect to firm performance, most of the firms experienced higher performance in terms of firm growth, profit growth, market performance, customer satisfaction and etc. These findings help further support recent quantitative findings (e.g., Patel et al., 2013; Shin and Konrad, 2017). In this sense, we argue that HPWS are an enabler of employee and firm performance. By investing effectively in HPWS, employees may acquire necessary knowledge, skills and motivation to effectively perform their job duties so as to repay their firm's investment. As such, they are more likely to contribute to the firm, thereby constituting the firm's competitive advantage, aligning it with the RBV (e.g., Barney, 1991).

Indicators of performance are considered as a critical tool to measure the effectiveness of firm outcomes. The analysis shows that different organisations employed different indicators of performance. Some focused-on indicators such as market performance, firm growth, profit 
and revenue. Others, however, drew attention to the indicators of service quality, customer satisfaction, employee commitment and employee turnover. It is noteworthy that some managers spoke of firm image and firm brand as part of their performance. Yet relatively little is known about these indicators in the extant literature. The study takes a useful initial step towards developing new indicators of performance, linking tangible dimensions of performance (e.g., market performance, financial performance) and intangible counterparts (e.g., brand and image). This evidence helps address research question 2.

The evidence also revealed that there was a link between HPWS and firm innovation (research question 3). In particular, the managers claimed that people are a contributor to organizational success because if organisations invest in developing employees' knowledge, skills and motivation, they will then return their effort to contribute to firm innovation (also see Behrens and Patzelt, 2018). For innovation to occur, organisations might leverage human capital to advance firm expertise for developing new products and services (Bouncken et al., 2018; Chen and Huang, 2009). This is because innovation initiatives are greatly dependent on individual skills, expertise and commitment as main ingredients in the value creation process (Youndt, Snell, Dean and Lepak, 1996). As such, HPWS are considered as the principle means by which organisations may shape employees' skills, attitudes and behaviour to fulfil their job tasks, thereby accomplishing firm goals (Chen and Huang, 2009). Despite its ability to make full use of employees' knowledge, skills and expertise, the organization should be able to acquire good capabilities in managing knowledge management tools in place to ensure that the human capital is optimally exploited in order to enhance firm expertise for innovation (Chen and Huang, 2009).

Also, of note is that the data analysis at Time 2 demonstrates that HPWS are the innovative management tool that helps firms strive and succeed in today's highly dynamic market environments. HPWS practices have been consistently and uniformly implemented across the studied firms over time. The results of Time 2 also suggest that HPWS are becoming more and more valuable for Vietnamese firms, and thus this is evidenced in ways that firms tend to invest more effectively in this system. As a result of their effective investments, the firms have experienced higher performance such as higher profits, market performance, employee attitudes and behaviours. It should also be noted that in order to respond to external environments, Vietnamese firms are aware that they need to shape HR structures that can help them to lessen the challenge and seize the opportunity of such environments. 


\section{Contributions and Implications}

The study makes several contributions to the SHRM literature. From a theoretical viewpoint, the results largely support the view that HR practices that represent the firm's strategic goals and investment could be a potential enabler to constitute the pool of unique workforce to yield competitive advantage to the firm (Shin and Konrad, 2017). This view is further explained by $\mathrm{RBV}$ that the human resources of a firm are presented as fundamental for a firm's competitiveness. In this regard, we hold that HPWS help firms respond to external environments by motivating employees to identify and respond to problems and opportunities arising from environmental changes (Shin and Konrad, 2017). This is further reinforced by institutional theory that organizations embedded in institutionally complex environments can create both a tension and an opportunity within HRM (Lewis et al., in press). HPWS are therefore the salient means that may help organizations respond to external pressures to gain their competitive position in the business landscape. We therefore argue that firms paying more attention to investing in people are likely to create a source of competitive advantage, thereby outperforming those that do not.

Furthermore, the study moves out of the common quantitative design and into the perceptions and voices of Vietnamese service managers via a means of qualitative content analysis. It is noteworthy that this becomes particularly significant since the majority of HPWS studies are undertaken using the quantitative approach, leaving much unknown about the real results of quantitative research because there is no qualitative research for commentators to compare with. Therefore, we argue that it is imperative that researchers pay more attention to undertaking qualitative studies in order to gradually narrow down research gaps in the SHRM.

More importantly, the study deviates from prior research my adopting the longitudinal design in order to examine the efficacy of HPWS on firm performance in a more in-depth manner, and also increase the accuracy of empirical evidence by validating the first wave of collected data with the second one. Specifically, the conceptualisation of HPWS, the efficacy of HPWS on performance, and the HPWS - innovation nexus is confirmed with empirical demonstrations. Furthermore, this study also highlights the importance of constructs like innovation, which potentially contributes to firm performance. It is noteworthy that this variable becomes significant when scholars call for exploring new mediating variables to fully unveil the HPWS and performance link (Werner, 2011). To this end, 'innovation' construct is 
considered as a prompt response to address this issue, thereby extending the relevant literature.

The study also yields salient implications for practitioners. The analysis demonstrated that HPWS could be a source of competitive advantage for firms if optimally implemented. This means that when firms adopt HPWS, they should pursue superior performance via the strategies to enhance positive behaviours rather than through a process of work intensification which may lead to negative responses for workers (Zhang, Di Fan and Zhu, 2014). To do this, management should utilise HR practices that could increase employee perceptions of a supportive work environment and trust between management and subordinates. With such positive consequences, employees will likely increase their innovative behaviours, thereby innovating in their work, and subsequently contributing to firm innovation (e.g., Desyllas et al., 2018; Nielsen et al., 2018).

This study can be viewed as a starting point for Vietnamese managers in general, and HR managers in particular to utilise 'best practices' as a win-win solution to drive their performance. Our results also revealed that innovation plays a critical role in the success of firms and organizations must invest in employees in order that they will acquire all knowledge, skills and motivation, and work in an environment that can allow them to activate their creativity. This is because skills and knowledge represent capital as they help improve productivity, while motivation and leadership are the key factors to drive employee creativity (Bednall et al., 2018). Consequently, they will respond to firm investment by working harder and more creatively, thereby contributing to firm innovation. Therefore, managers are advised to bear this mind in order to achieve their strategic goals.

\section{Limitations and Direction for Future Research}

This study has some limitations. Firstly, because the data analysed here is based on qualitative research, it may be less objective and cannot be generalised to the entire service sector. Despite its in-depth data analysis, the mixed methods should be undertaken to complement each other and limit the weaknesses of one method or another. Secondly, because our data are mainly based on managerial reporting, the managers may exaggerate the extent of sophisticated HRM practices in their firms. This may affect the reliability of the data. A final limitation concerns the sample size as a large number of respondents may ensure a more reliable and comprehensive data. Despite its certain weaknesses, the study provides an 
insightful picture of how and why HPWS influences performance by deploying the two waves of data collection to ensure the validity and reliability of the collected data.

\section{CONCLUSION}

We focus in this study on the analysis of why and how HPWS exist and are diffused in the context of Vietnam, and also what effects HPWS have on firm performance. The results reveal that HPWS are the key means that positively influences performance when properly implemented. The managers also highlight the important link between HPWS and firm innovation. For innovation to occur, employees should be optimally invested in order that they will possess the knowledge, skills and commitment needed for high performing and creative activation. In doing so, firms must adopt well designed HPWS practices that can advance the skills, knowledge of employees, and motivate them to perform at their highest potential at work. Furthermore, managers should also enable their employees to work in a work environment conductive to innovative behaviours. These strategies are considered particularly critical for firms counting on innovation and in a managerial spirit to strive in today's turbulent markets.

\section{REFERENCES}

Aryee, S., Walumbwa, F. O., Seidu, E. Y., and Otaye, L. E. (2012), "Impact of highperformance work systems on individual-and branch-level performance: test of a multilevel model of intermediate linkages". Journal of Applied Psychology, Vol. 97 No. 2, pp. 287-290.

Barney, J. (1991), “Firm resources and sustained competitive advantage". Journal of Management, Vol. 17 No. 1, pp. 99-120.

Bednall, T., Rafferty, A.E., Shipton, H., Sanders, K. and Jackson, C.J. (2018), "Innovative behaviour: How much transformational leadership do you need?" British Journal of Management, Vol. 29 No. 4, pp. 796-816.

Behrens, J. and Patzelt, H. (2018), "Incentives, resources and combinations of innovation radicalness and innovation speed". British Journal of Management, Vol. 29 No. 4, pp. 691711.

Bouncken, R.B., Fredrich, V., Ritala, P. and Kraus, S. (2018), "Coopetition in new product development alliances: Advantages and tensions for incremental and radical innovation". British Journal of Management, Vol. 29 No. 3, pp. 391-410.

Chen, C. J., and Huang, J. W. (2009), "Strategic human resource practices and innovation performance - The mediating role of knowledge management capacity'. Journal of Business Research, Vol. 62 No. 1, pp. 104-114. 
Cox, A., Hannif, Z., and Rowley, C. (2014), "Leadership styles and generational effects: Examples of US companies in Vietnam'. The International Journal of Human Resource Management, Vol. 25 No. 1, pp. 1-22.

Datta, D. K., Guthrie, J. P., and Wright, P. M. (2005), "Human resource management and labor productivity: does industry matter?'. Academy of Management Journal, Vol. 48 No. 1, pp. 135-145.

Damanpour, F., Sanchez-Henriquez, F. and Chiu, H.H. (2018), "Internal and external sources and the adoption of innovations in organizations". British Journal of Management, Vol. 29 No. 4, 712-730.

Desyllas, P., Miozzo, M., Lee, H-F. and Miles, I. (2018), "Capturing value from innovation in knowledge-intensive business service firms: The role of competitive strategy". British Journal of Management, Vol. 29 No. 4, pp. 769-795.

Do, H., Budhwar, P. S., and Patel, C. (2018), "Relationship between innovation led HR policy, strategy, and firm performance: A serial mediation investigation'. Human Resource Management. Vol. 57 No. 5, pp. 1271-1284.

Do, H., Budhwar, P. S., and Patel, C. (2015, January), 'High-Performance Work Systems and Organizational Performance'. In Academy of Management Proceedings (Vol. 2015, No. 1, pp. 14359). Academy of Management.

Flinchbaugh, C., Li, P., Luth, M. T., and Chadwick, C. (2016), "Team-level high involvement work practices: investigating the role of knowledge sharing and perspective taking'’. Human Resource Management Journal, Vol. 26 No. 2, pp. 134-150.

Fu, N., Flood, P. C., Bosak, J., Morris, T., and O'Regan, P. (2015), “How do high performance work systems influence organizational innovation in professional service firms?'. Employee Relations, Vol. 37 No. 2, pp. 209-231.

Gerrard, B. and Lockett, A. (2018), “Team-specific human capital and performance”. British Journal of Management, Vol. 29 No. 1, pp. 10-25.

Hughes, M., Rigtering, J.P.C., Covin, J.G., Bouncken, R.B. and Kraus, S. (2018), "Innovative behaviour, trust and perceived workplace performance. British Journal of Management, Vol. 29 No. 4, pp. 750-768.

Hughes, M., Powell, T.H., Chung, L. and Mellahi, K. (2017), "Institutional and resource-based explanations for subsidiary performance. British Journal of Management, Vol. 28 No. 3, pp. 407-424.

Heffernan, M., and Dundon, T. (2016), "Cross-level effects of high-performance work systems (HPWS) and employee well-being: the mediating effect of organisational justice'. Human Resource Management Journal, Vol. 26 No. 2, pp. 211-231.

Hsieh, H. F., and Shannon, S. E. (2005), "Three approaches to qualitative content analysis'. Qualitative Health Research, Vol. 15 No. 9, pp. 1277-1288.

Huang, L. C., Ahlstrom, D., Lee, A. Y. P., Chen, S. Y., and Hsieh, M. J. (2016), "High performance work systems, employee well-being, and job involvement: An empirical study'. Personnel Review, Vol. 45 No. 2, pp. 296-314. 
Jiang, K., Lepak, D. P., Hu, J., and Baer, J. C. (2012), "How does human resource management influence organizational outcomes? A meta-analytic investigation of mediating mechanisms". Academy of Management Journal, Vol. 55 No. 6, pp. 1264-1294.

Kolh, K. S. (2007), “Americans doing business in Vietnam: communication differences'. International Business Communication, pp. 1-5.

Lewis, C. A., Cardy, L. R., and Huang, S. R. L. (In press), “'Institutional theory and HRM: A new look'. Human Resource Management Review.

Liao, H., Toya, K., Lepak, D. P., and Hong, Y. (2009), “'Do they see eye to eye? Management and employee perspectives of high-performance work systems and influence processes on service quality". Journal of Applied Psychology, Vol. 94 No. 2, pp. 371-391.

Messersmith, J. G., Patel, P. C., Lepak, D. P., and Gould-Williams, J. S. (2011), “Unlocking the black box: Exploring the link between high-performance work systems and performance'. Journal of Applied Psychology, Vol. 96 No. 6, pp. 1105-1118.

Montague, A. (2013), "Vocational and skill shortages in Vietnamese manufacturing and service sectors, and some plausible solutions". Asia Pacific Journal of Human Resources, Vol. 51 No. 2, pp. 208-227.

Nielsen, J.A., Mathiassen, L. and Hansen, A.H. (2018), "Exploration and exploitation in organizational learning: A critical application of the 4I model. British Journal of Management, Vol. 29 No. 4, pp. 835-850.

O’Dwyer, B. (2004), Qualitative data analysis: illuminating a process for transforming a 'messy'but 'attractive' 'nuisance'. In The real life guide to accounting research (pp. 391-407).

Pak, J., and Kim, S. (2018), “Team manager's implementation, high performance work systems intensity, and performance: a multilevel investigation'. Journal of Management, Vol. 44 No. 7, pp. 2690-2715.

Patel, P. C., Messersmith, J. G., and Lepak, D. P. (2013), "Walking the tightrope: An assessment of the relationship between high-performance work systems and organizational ambidexterity'. Academy of Management Journal, Vol. 56 No. 5, pp. 1420-1442.

Qiao, K., Khilji, S., and Wang, X. (2009), "High-performance work systems, organizational commitment, and the role of demographic features in the People's Republic of China". The International Journal of Human Resource Management, Vol. 20 No. 11, pp. 2311-2330.

Rowley, C., Quang, T., and Warner, M. (2007), “To what extent can management practices be transferred between countries?: The case of human resource management in Vietnam'. Journal of World Business, Vol. 42 No. 1, pp. 113-127.

Shin, D., and Konrad, A. M. (2017), "Causality between high-performance work systems and organizational performance', Journal of Management, Vol. 43 No. 4, pp. 973-997.

Sun, L. Y., Aryee, S., and Law, K. S. (2007), “High-performance human resource practices, citizenship behavior, and organizational performance: A relational perspective'. Academy of Management Journal, Vol. 50 No. 3, pp. 558-577.

Werner, S. (2011), "High performance work systems in the global context: A commentary essay”. Journal of Business Research, Vol. 64 No. 8, pp. 919-921. 
Xia, T. and Liu, X. (2018), "Foreign competition and innovation: The mediating role of imitation. British Journal of Management, Vol. 29 No. 3, pp. 464-482.

Youndt, M. A., Snell, S. A., Dean Jr, J. W., and Lepak, D. P. (1996), "Human resource management, manufacturing strategy, and firm performance'. Academy of Management Journal, Vol. 39 No. 4, pp. 836-866.

Zhang, M., Di Fan, D., and Zhu, C. J. (2014), “High-performance work systems, corporate social performance and employee outcomes: Exploring the missing links". Journal of Business Ethics, Vol. 120 No. 3, pp. 423-435.

TABLE 1 (click here to go back!)

Interviewees' role and industry sector

\begin{tabular}{llllll}
\hline Role of Interviewee & & & & & \\
\hline Service Industry & HRM & FM & CEO & GM & Total \\
Banking & 2 & 2 & 0 & 1 & 5 \\
Pharmaceuticals & 3 & 1 & 1 & 0 & 5 \\
Telecommunications & 2 & 1 & 0 & 1 & 4 \\
Insurance & 1 & 1 & 0 & 1 & 3 \\
Total & 8 & 5 & 1 & 3 & 17
\end{tabular}

Note: $\mathrm{HRM}=$ human resource manager; $\mathrm{FM}$ = firm manager; $\mathrm{CEO}=$ chief executive officer;

$\mathrm{GM}=$ general manager. A total of 14 male and 3 female managers participated in the interviews. 
APPENDIX A (click here to go back!)

\section{Complementary quotes in the Results section}

\begin{tabular}{|c|c|c|c|c|}
\hline No & Theme & Page & Time & Quotes \\
\hline 1 & \multirow[t]{2}{*}{ Conceptualization of HPWS } & 12 & 1 & $\begin{array}{l}\text { HPWS are a new management system with the aim of facilitating employees } \\
\text { 'behavior, attitudes and skills in order for them to enhance their job } \\
\text { performance, which then results in firm performance (TFM). }\end{array}$ \\
\hline 2 & & 12 & 2 & $\begin{array}{l}\text { HPWS are a system designed to promote sustainable development if well } \\
\text { implemented in a particular condition of every organization. If organizations } \\
\text { utilize HPWS in an optimal fashion, they are more likely to achieve } \\
\text { enhanced economic performance and sustainability (PHRM). }\end{array}$ \\
\hline 3 & \multirow[t]{2}{*}{ Effects of HPWS adoption } & 14 & 1 & $\begin{array}{l}\text { Since our implementation of these practices, we have witnessed positive } \\
\text { changes in employee attitudes, behaviors and commitment. For the firm, we } \\
\text { have experienced increases in market performance, revenue, profit and lower } \\
\text { turnover. (Insurance company, General Manager, Time 1). }\end{array}$ \\
\hline 4 & & 14 & 1 & $\begin{array}{l}\text { Yes, they are. While right recruitment and training policies help select and } \\
\text { train the most suitable employees for the organisation, other policies affect } \\
\text { employees' attitudes towards their work tasks. It means that all the above } \\
\text { HR practices may improve productivity of the organization. For example, } \\
\text { reward and bonus policy has a direct impact upon the quality of the services } \\
\text { as they provoke competition among the employees. This helps increase }\end{array}$ \\
\hline
\end{tabular}




\begin{tabular}{|l|l|l|l|l|}
\hline 6 & $\begin{array}{l}\text { HPWS and Innovation } \\
\text { Relationship }\end{array}$ & 15 & 1 & $\begin{array}{l}\text { higher sales for the company (THRM). } \\
\text { If the HR practices create an open atmosphere where employees are happy } \\
\text { and satisfied with their work, the employees will be more likely to share } \\
\text { their ideas. And if the ideas are given certain prominence, they may nurture } \\
\text { creativity and thus can help impulse firm innovation. --- the top management } \\
\text { in this case must be creative, decisive and knowledgeable enough to develop } \\
\text { an innovative HR strategy that appreciates talented people, welcomes } \\
\text { creative ideas and knows how to find resources to implement practical ideas } \\
\text { (PCEO). }\end{array}$ \\
\hline 7 & 16 & 1 & $\begin{array}{l}\text { Yes, they do. If the management really wants to innovate the firm, they will } \\
\text { spend efforts, time and money implementing it. In case of our company, we } \\
\text { determine that people are a decisive factor to the success or failure of the } \\
\text { innovation process. ---in short, when we innovate a department, the whole } \\
\text { company needs to be innovated accordingly. Hence, HR practices are } \\
\text { believed to have an influence on firm innovation (THRM). }\end{array}$ \\
\hline
\end{tabular}


TABLE 2 (click here to go back!)

\section{Summary of HPWS Practices within Vietnamese Firms}

\begin{tabular}{|c|c|c|c|c|}
\hline No & $\begin{array}{l}\text { HPWS } \\
\text { Practices }\end{array}$ & $\begin{array}{l}\text { Percentage } \\
\text { of } \\
\text { Respondents }\end{array}$ & Methods of Applicability & Remarks \\
\hline 1 & $\begin{array}{l}\text { Recruitment } \\
\text { and selection }\end{array}$ & $100 \%$ & $\begin{array}{l}\text { Qualifications, academic } \\
\text { achievement, CVs, knowledge tests } \\
\text { and interviews }\end{array}$ & $\begin{array}{l}\text { Most of the managers underscore the importance of this } \\
\text { practice to the quality of employees and higher performance } \\
\text { of their firms. }\end{array}$ \\
\hline 2 & $\begin{array}{l}\text { Training and } \\
\text { development }\end{array}$ & $88.2 \%$ & $\begin{array}{l}\text { On the job-training, off the job } \\
\text { training, peer training, mentoring }\end{array}$ & $\begin{array}{l}\text { This HR practice enables employees to acquire knowledge, } \\
\text { skills and expertise required to fulfill their job duties, } \\
\text { providing better quality of service for customers and } \\
\text { accommodating customers' needs. }\end{array}$ \\
\hline 3 & Wage policy & $70.5 \%$ & $\begin{array}{l}\text { Common ground salary policy, pay } \\
\text { lucrative income for employees, } \\
\text { bonuses for public holidays, New } \\
\text { Year and Lunar New Year }\end{array}$ & $\begin{array}{l}\text { Each company implements its different policies of salary for } \\
\text { their employees. However, they are all fully aware that good } \\
\text { pay policies are likely to motivate their employees to } \\
\text { contribute more to their firm performance. }\end{array}$ \\
\hline 4 & $\begin{array}{l}\text { Innovation } \\
\text { Strategy } \\
\text { Execution }\end{array}$ & $41.1 \%$ & $\begin{array}{l}\text { Developing the workforce and the } \\
\text { management, renovating the work } \\
\text { process, researching the market, and } \\
\text { providing the new services, etc. }\end{array}$ & $\begin{array}{l}\text { The managers are aware that innovation strategies are a must } \\
\text { for firms to exist and strive in times of economic crisis. } \\
\text { Therefore, it is important to have the participation of both } \\
\text { managers and employees to jointly translate these strategies }\end{array}$ \\
\hline
\end{tabular}




\begin{tabular}{|c|c|c|c|c|}
\hline & & & & into practice. \\
\hline 5 & $\begin{array}{l}\text { Innovation- } \\
\text { Led HR } \\
\text { Policy }\end{array}$ & $41.1 \%$ & $\begin{array}{l}\text { Recruiting the talented, training and } \\
\text { using them appropriately }\end{array}$ & $\begin{array}{l}\text { In order to maintain, stabilize and develop human resources in } \\
\text { accordance with a company's development strategies, the } \\
\text { company must execute new and innovative HRM systems in } \\
\text { order to have breakthroughs in the human factors to create a } \\
\text { source of competitive advantage. }\end{array}$ \\
\hline 6 & $\begin{array}{l}\text { Working } \\
\text { Environment }\end{array}$ & $52.9 \%$ & $\begin{array}{l}\text { Showing concern for workers' } \\
\text { wellbeing so as to secure devotion } \\
\text { and loyalty, creating a friendly work } \\
\text { environment. }\end{array}$ & $\begin{array}{l}\text { The managers highlight the importance of the supportive work } \\
\text { environment for employees to feel psychologically safe to } \\
\text { innovate and perform their work in a most creative and } \\
\text { effective manner. }\end{array}$ \\
\hline 7 & Promotion & $35.3 \%$ & $\begin{array}{l}\text { Offering professional development } \\
\text { training courses and clear career } \\
\text { roadmap for potential employees, } \\
\text { executing promotion policy. }\end{array}$ & $\begin{array}{l}\text { The interviewees are all aware that by deploying effective } \\
\text { promotion policies, potential candidates will try their best to } \\
\text { demonstrate their abilities to be promoted, thereby working to } \\
\text { their fullest potential and contributing to firm performance. }\end{array}$ \\
\hline 8 & $\begin{array}{l}\text { Performance } \\
\text { Appraisal }\end{array}$ & $29.4 \%$ & $\begin{array}{l}\text { Job achievement, work attitude and } \\
\text { effort, customer satisfaction, and } \\
\text { potential for future improvement, } \\
\text { sales growth; attraction of new } \\
\text { customers; retention of existing } \\
\text { customers; and cost reduction. }\end{array}$ & $\begin{array}{l}\text { The criteria of performance appraisals implemented in each } \\
\text { organization varied due to firms' strategies, goals and targets. } \\
\text { The managers understand that appropriate performance } \\
\text { appraisals will contribute to both individual and firm } \\
\text { performance outcomes. }\end{array}$ \\
\hline
\end{tabular}


TABLE 3 (click here to go back!)

Indicators of Performance

\begin{tabular}{lll}
\hline No & Indicators of Performance & Percentage of Interviewees \\
\hline 1 & Profit & $70.5 \%$ \\
2 & Revenue & $58.8 \%$ \\
3 & Market performance & $41.1 \%$ \\
4 & Customer satisfaction & $23.5 \%$ \\
5 & Labor productivity & $23.5 \%$ \\
6 & Turnover intention & $17.6 \%$ \\
7 & Service quality & $11.7 \%$ \\
8 & Firm growth & $11.7 \%$ \\
\hline
\end{tabular}

